\title{
PERAN KARANG TARUNA DALAM PEMBERDAYAAN MASYARAKAT KELURAHAN SEI GOHONG KECAMATAN BUKIT BATU KOTA PALANGKA RAYA
}

\author{
Muhamad Aminudin ${ }^{1}$, Eddy Lion $^{2}$, Yuyuk Tardimanto ${ }^{3}$ \\ ${ }^{1,2,3}$ Prodi PPKn, Universitas Palangka Raya \\ Jl. Rajawali Km.3.5 \\ Email: Muhamadaminudin823@gmail.com
}

\begin{abstract}
Abstrak:
Permasalahan dalam penelitian ini adalah :"Peran Karang Taruna Dalam Pemberdayaan Masyarakat Kelurahan Sei Gohong Kecamatan Bukit Batu Kota Palangka Raya”. Penelitian ini Di bahas Dengan Tujuan Untuk mengetahui Peran Karang Taruna Dalam Pemberdayaan Masyarakat Kelurahan Sei Gohong Kecamatan Bukit Batu Kota Palangka Raya. Karang taruna berperan sebagai wadah perkumpulan pemuda dalam melakukan kegiatan kemasyarakatan dalam bidang olah raga, seni budaya dan bidang - bidang lain seperti kegiatan - kegiatan yang lain terutama dalam bidang keamanan, bidang kesenian dan bidang uasaha melalui peminjaman dana bergulir. Metode penelitian ini menggunakan kualitatatif, dengan pengumpulan data wawancara dan studi dokumentasi melalui teknik purpossive sampling. Faktor penghambatnya / Kendala yang dihadapi Karang Taruna di Kelurahan Sei Gohong adalah yang utama adalah ketersediaan dana yang kurang, Kantor Sekretariat Belum ada, sumberdaya manusia kemudian rapat kordinasi jarang, sebagian kegiatan dalam program sudah dikerjakan oleh pihak kelurahan.
\end{abstract}

Kata Kunci: Peranan, Karang Taruna, Pemberdayaan Masyarakat

\begin{abstract}
:
The problem in this research is: "The Role of Youth Organization in Community Empowerment in Sei Gohong Village, Bukit Batu District, Palangka Raya City". This research is discussed with the aim to find out the role of Youth Organization in Community Empowerment in Sei Gohong Village, Bukit Batu Subdistrict, Palangka Raya City. Youth organization plays a role as youth association in carrying out community activities in the field of sports, arts and culture and other fields such as other activities, especially in security, arts and uasaha fields through borrowing revolving funds. This research method uses qualitative, by collecting interview data and studying documentation through purposive sampling techniques. The inhibiting factors / obstacles faced by Youth Organization in Sei Gohong Kelurahan are the main ones are the lack of funds, Secretariat
\end{abstract}


Office Not yet available, human resources and coordination meetings are sparse, some activities in the program have been carried out by the kelurahan.

Keywords: Role, Youth Organization, Community Empowerment

\section{A. PENDAHULUAN}

Demi mencapai tujuan nasional tersebut dilaksanakan berbagai upaya pembangunan dan pemberdayaan disegala bidang, baik sumber daya alam maupun sumber daya manusianya(Karliani, 2014). Salah satu sumber daya yang sering menjadi permasalahan yaitu sumber daya manusia, yang berhubungan erat dengan kualitas manusia yang pada dasarnya sumber daya manusia itu adalah bagian dan generasi muda(Karliani, Kartadinata, Winataputra, \& Komalasari, 2019). Karena generasi muda inilah yang akan kelak meneruskan tongkat estafet kepemimpinan dimasa yang akan datang, sehingga kita membutuhkan generasi yang terampil, berakhlak, bermoral serta cinta tanah air dan dapat diandalkan di tengah masyarakat terutama bangsa dan negara(Saefulloh, 2018a). Peranan generasi muda sebagai pilar, penggerak, dan pengawal jalannya reformasi dan pembangunan sangat diharapkan. Generasi muda adalah remaja yang nantinya akan menjadi tunas harapan dan modal pembangunan bangsa yang akan datang(Saefulloh, 2018b).

\section{B. KAJIAN TEORI}

Karang Taruna merupakan suatu wadah organisasi bagi para pemuda Desa. Karang Taruna yang merupakan sebuah wadah bagi generasi muda di sebuah Desa yang diharapkan menjadi tulang punggung bangsa dan negara. Pemberdayaan masyarakat adalah merupakan suatu arah kebijakan yang sangat penting dalam program penanggulangan ketertinggalan. Penanggulan masyarakat dalam ketertinggalan bertujuan agar masyarakat dapat mengakses peningkatan kualitas kehidupan dalam berbagai aspek, seperti pendidikan, kesehatan, kesejahteraan, dan lainnya.

Jadi yang dimaksud dengan peran karang taruna dalam pemberdayaan masyarakat adalah merupakan suatu wadah organisasi bagi para pemuda Desa(Arief \& Adi, 2014). Karang Taruna yang merupakan sebuah wadah bagi generasi muda di sebuah Desa yang diharapkan menjadi tulang punggung bangsa dan negara dalam pemberdayaan masyarakat adalah merupakan suatu arah kebijakan yang sangat penting dalam program penanggulangan ketertinggalan. Penanggulan masyarakat dalam ketertinggalan bertujuan agar masyarakat dapat mengakses peningkatan kualitas kehidupan dalam berbagai aspek, seperti pendidikan, kesehatan, kesejahteraan, dan lainnya(Ashary, 2016).

\section{METODE PENELITIAN}

Dalam penelitian ini, peneliti menggunakan metode kualitatif yang digunakan untuk mengetahui hasil data yang berupa kata - kata tertulis maupun lisan dari orang-orang atau perilaku yang diamati, baik secara observasi, wawancara maupun dokumentasi. Pendekatan penelitian yang digunakan dalam penelitian adalah kualitatif deskriptif karena dalam penelitian ini menghasilkan kesimpulan berupa data yang menggambarkan secara rinci, bukan data yang berupa angka-angka. Hal ini karena pendekatan kualitatif sebagai prosedur penelitian yang menghasilkan data deskriptif berupa kata-kata tertulis 
atau lisan dari orang-orang dan perilaku yang diamati. Penelitian kualitatif adalah suatu pendekatan ilmiah yang mengungkap situasi sosial tertentu dengan mendeskripsikan kenyataan secara benar, dibentuk oleh kata-kata berdasarkan teknik pengumpulan analisis data yang relevan yang diperoleh dari situasi yang alamiah.

\section{HASIL DAN PEMBAHASAN}

\section{Kelurahan Sei Gohong}

Kelurahan Sei Gohong adalah salah satu dasar milik pemerintah dan masih aktif sampai dengan sekarang. Kelurahan sei gohong beralamat di JL. Karya Baru kecematan Bukit Batu Kota Palangka Raya, untuk luas wilayah kelurahan Sei Gohong yaitu seluas 12. 000 Ha. Dengan jumlah penduduk 2113 jiwa (data bulan Juni 2019) dengan jumlah Kepala Keluarga 151 KK. Penduduk Kelurahan Garantung 40\% memeluk Agama Islam, 50\% memeluk agama kristen dan 20\% hindu kaharingan. Yang memiliki 1 buah Musholla, dan 1 buah Gereja. Kelurahan Sei Gohong terdiridari 3 RT dan 3 RW.

\section{Kondisi Geografis}

Keharmunisan hubungan yang timbal balik yang baik antara manusia dengan lingkungan merupakan salah satu sebab pokok majunya tingkat kehidupan dan penghidupan masyarakat. Dengan mengetahui keadaan geografis suatu daerah maka dapat diketahui potensi-potensi apa saja yang terdapat di daerah tersebut dan bagaimana kemampuan masyarakat dalam memanfaatkan dan mengembangkan potensi tersebut dalam upaya memperbaiki taraf hidupnya.

\section{Keadaan Geografis Kelurahan Sei Gohong}

Keadaan penduduk suatu daerah akan mempengaruhi keadaan sosial ekonomi daerah yang bersangkutan. Penduduk menjadi potensi positif dalam mendukung pembangunan sebagai modal dasar yang dapat dibina dan dikerahkan sebagai tenaga kerja yang efektif dan menguntungkan bagi usaha pembangunan di segala bidang, karena penduduk merupakan subjek sekaligus objek pembangunan yang akan dilaksanakan.

\section{Demografi Kelurahan Sei Gohong}

Keadaan penduduk suatu daerah akan mempengaruhi keadaan sosial ekonomi daerah yang bersangkutan. Penduduk menjadi potensi positif dalam mendukung pembangunan sebagai modal dasar yang dapat dibina dan dikerahkan sebagai tenaga kerja yang efektif dan menguntungkan bagi usaha pembangunan di segala bidang, karena penduduk merupakan subjek sekaligus objek pembangunan yang akan dilaksanakan.

\section{Pembahasan}

Dalam uraian yang akan di bahas dalam penelitian ini ada tiga hal yang menjadi masalah dalam penelitian ini antara lai sebagai berikut:

1. Peran karang taruna dalam pemberdayaan masyarakat Kelurahan Sei Gohong Kecamatan Bukit Batu Kota Palangka Raya.

2. Kendala-kendala yang dihadapi karang taruna dalam pemberdayaan masyarakat Kelurahan Sei Gohong Kecamatan Bukit Batu Kota Palangka Raya. 
3. Mengatasi kendala-kendala yang dihadapi karang taruna dalam pemberdayaan masyarakat Kelurahan Sei Gohong Kecamatan Bukit Batu Kota Palangka Raya.

4. Faktor pendukung karang taruna dalam pemberdayaan masyarakat Kelurahan Sei Gohong Kecamatan Bukit Batu Kota Palangka Raya.

Dari keempat masalah diatas akan dirinci dan dianalisis bahwa setiap masalah sudah tentu ada sebuah jawaban dan ada jalan keluar dari hasil temuan dilapangan dan dikaji dari berbagai teori dan pendapat para ahli dan melihat penelitian yang relevan terdahulu.

1. Peran karang taruna dalam pemberdayaan masyarakat Kelurahan Sei Gohong Kecamatan Bukit Batu Kota Palangka Raya

Karang teruna mempunyai peran dalam bidang kepemudaan dan organisasi tentang kegiatan kepemudaan dan masyarakat dikelurahan sei gohong, karang taruna juga sebagai wadah anak - anak muda berkumpul dalam melakukan kegiatan bidang kepemudaan masyarakat.

Dikatakan bahwa peran karang taruna dalam pemberdayaan masyarakat Kelurahan Sei Gohong Kecamatan Bukit Batu Kota Palangka Raya karang taruna merupakan wadah atau perkumpulan anak muda dalam hal melakukan program mereka dalam membantu kemajuan desa sehingga karang taruna mempunya tempat untuk melakukan kegiatan - kegiatan kemasyarakatan seperti, kegiatan kepemudaan dan olah raga, keamanan, kebersihan wilayah, parkir kendaraan roda dua atau empat ditempat objek wisata.

2. Kendala-kendala yang dihadapi karang taruna dalam pemberdayaan masyarakat Kelurahan Sei Gohong Kecamatan Bukit Batu Kota Palangka Raya

Sebagai kendala yang menjadi penghambat Peran Karang Taruna Dalam Pemberdayaan Masyarakat Kelurahan Sei Gohong Kecamatan Bukit Batu Kota Palangka Raya dalam kelaksanakan kegiatan masyarakat dilingkunganan sekitar, tidak dilakukan oleh seluruh anggota dalam menjalankan kegiatan-kegiatan tersebut. Sering kali tidak efektif dengan membawa urusan-urusan pribadi yang sifatnya keterwakilan individu. Beberapa anggota Karang Taruna yang ikut terlibat dalam setiap pembangunan atau kegiatan-kegiatan masyarakat yang ada di lingkungan sekitar adalah anggota yang tidak memiliki kompeten dan kemampuan yang tinggi dalam bidang pembangunan masyarakat, baik individu maupun kelompok serta mempunyai latar belakang pengetahuan yang kurang memadai.

3. Mengatasi kendala-kendala yang dihadapi karang taruna dalam pemberdayaan masyarakat Kelurahan Sei Gohong Kecamatan Bukit Batu Kota Palangka Raya.

Cara mengatasi kendala-kendala yang menjadi penghambat Pemberdayaan Masyarakat Kelurahan Sei Gohong Kecamatan Bukit Batu Kota Palangka Raya dalam melaksanakan kegiatan masyarakat dilingkunganan sekitar yakni dengan cara rapat antara anggota karang taruna dengan aparatur desa dalam rangka mengatasi permasalahan yang terjadi di masyarakat.

4. Faktor pendukung karang taruna dalam pemberdayaan masyarakat Kelurahan Sei Gohong Kecamatan Bukit Batu Kota Palangka Raya. 
Dengan kewenangan yang dimiliki Karang Taruna yang meliputi sebagai motivator, inisiator dalam pembangunan dan katalisator keserasian sosial. KarangTaruna adalah wadah pemupukan karakter bangsa, yang jika dikembangkan secara kreatif akan menjadi awal kekuatan bangsa. Bentuk partisipasi Karang Taruna terhadap keikutsertaan pemuda untuk melaksanakan kegiatan desa/Kelurahan dalam pembangunan masyarakat yang juga sebagai mitra penyelenggara pemerintahan di Kelurahan.

\section{E. KESIMPULAN}

Berdasarkan hasil analisis data maka dapat disimpulkan sebagai berikut: Peran karang taruna berperan sebagai wadah perkumpulan pemuda dalam melakukan kegiatan kemasyarakatan dalam bidang olah raga, seni budaya dan bidang - bidang lain seperti kegiatan - kegiatan yang lain terutama dalam bidang keamanan,bidang kesenian dan bidang uasaha melalui peminjaman dana bergulir. Faktor penghambatnya / Kendala yang dihadapi Karang Taruna di Kelurahan Sei Gohong adalah yang utama adalah ketrsediaan dana yang kurang, Kantor Sekretariat Belum ada, sumberdaya daya manusia kemudian rapat kordinasi jarang, seabagian kegiatan dalam program sudah dikerjakan oleh pihak kelurahan. Setiap kegiatan yang sifatnya memerlukan biaya maka pihak karang taruna di Kelurahan Sei Gohong melakukan kegiatan dengan cara swadaya masyarakat, serta mencari donator atas kegiatan yang mereka lakukan seperti mencari sponsor dari pemerintah ataupun pihak swasta.

\section{F. SARAN DAN UCAPAN TERIMA KASIH}

Memperhatikan beberapa simpulan dari hasil penelitian di atas, maka dapat disampaikan saran-saran sebagai berikut.

1. Dari penelitian diatas maka penulis memberikan saran kepada Karang Taruna Di Kelurahan Sei Gohong agar tetap bekerja keras dan terus terlibat dalam setiap pembangunan, terus berkomunikasi dengan masyarakat serta siap terhadap situasi dan kondisi masyarakat di Kelurahan Sei Gohong. Yang terpenting adalah selalu bermitra dengan lembaga-lembaga yang ada diluar Karang Taruna seperti pemerintah daerah dan lembaga sosial lainnya.

2. Bagi pengurus Karang Taruna sebaiknya agar dapat melakukan kegiatan yang lebih bervariatif misalnya menyelenggarakan seminar motivasi dengan narasumber yang berkompetensi dibidangnya, mengadakan pelatihan-pelatihan guna meningkatkan pengetahuan paraanggota, dan bagi anggota yang belum berpartisipasi secara aktif sangat diharapkan untuk turut serta dalam setiap kegiatan yang dilaksanakan, berkaitan dengan terbatasnya anggaran yang diperoleh Karang Taruna maka diharapkan baik para penggurus maupun anggota Karang Taruna diwajibkan melakukan iuran khusus guna menopang kebutuhan dasar Karang Taruna.

3. Karang Taruna sebaiknya harus dapat bermanfaat bagi masyarakat sesuai dengan tugasdan fungsinya, dan selalu berada digarda terdepan bagi kesuksesan pembangunanmasyarakat dan lingkungannya. Dengan adanya dukungan sumber daya yang adadi lingkungan sekitar, maka ini merupakan modal awal bagi keberhasilan program-program Karang Taruna. 


\section{REFERENSI}

Arief, M. R., \& Adi, A. S. (2014). Peran karang taruna dalam pembinaan remaja di dusun candi Desa Candinegoro Kecamatan Wonoayu Kabupaten Sidoarjo. Kajian Moral Dan Kewarganegaraan.

Ashary, L. (2016). Optimalisasi Pemberdayaan Karang Taruna Dalam Pengembangan Desa Silomukti Kabupaten Situbondo. In Dinamika Global : Rebranding Keunggulan Kompetitif Berbasis Kearifan Lokal. https://doi.org/10.1109/APCCAS.2010.5775034

Direktorat Bina Karang Taruna. 2005. Buku Pedoman Dasar Karang Taruna. Departemen Sosial R.I

Bakrie, Masyukri. (2002) Metode Penelitian Kualitatif. Lembaga Penelitian Universitas Palangka Raya.

Eddy Lion \& Helmud 2013, Metode Penelitian Kuantitatif. Yogyakarta, Pusaka antara Surabaya.

Karliani, E. (2014). Membangun Civic Engagement Melalui Model Service Learning Untuk Memperkuat Karakter Warga Negara. Jurnal Pendidikan Pancasila Dan Kewarganegaraan.

Karliani, E., Kartadinata, S., Winataputra, U. S., \& Komalasari, K. (2019). Indonesian civic engagement among college students. Journal of Human Behavior in the Social Environment. https://doi.org/10.1080/10911359.2019.1571980

Saefulloh, A. (2018a). PERAN PENDIDIK DALAM PENERAPAN INTERNET SEHAT MENURUT ISLAM. Al-Tadzkiyyah: Jurnal Pendidikan Islam. https://doi.org/10.24042/atjpi.v9i1.2709

Saefulloh, A. (2018b). Rehabilitasi Eks-Pecandu Narkoba Melalui Pendekatan Agama Islam. ISLAMIC COUNSELING: Jurnal Bimbingan Konseling Islam, 2(1), 43. https://doi.org/10.29240/jbk.v2i1.377

Sugiyono, 2012. Metode Penelitian Pendidikan Pendekatan Kuantitatif, Kualitatif dan R E D. Bandung : PT. Alfabeta 